\title{
Using Google Classroom in Enhancing Communicative Grammar Use and Attitudes of Non-English Specialized Post Graduates
}

\author{
Dr. Haggag Mohamed Haggag \\ Lecturer of Curricula \& TEFL Methodology \\ Hurghada Faculty of Education, South Valley University, Egypt
}

Doi:10.19044/esj.2019.v15n1p261

URL:http://dx.doi.org/10.19044/esj.2019.v15n1p261

\begin{abstract}
This research integrates virtual language learning and the Communicative Language Teaching CLT approach for developing grammatical performance and attitudes towards English grammar use. It follows the one-group quasi-experimental design. Participants were randomly selected from the postgraduates General Diploma (41) at Hurghada Faculty of Education, Egypt. Instruments of the research included communicative grammar module through Google classroom application, communicative grammar test and a scale about the attitude towards English grammar use. It discussed how to design, instruct and assess a communicative grammar module by using Google Classroom virtual class. Results of the study showed a development in both the performance of participants' use of English grammar as well as their positive attitudes towards grammar use. Following a one-group quasi-experimental design, the obtained results showed a development in participants' grammar use $(0.001)$ and also their positive attitudes (0.001) towards using grammar. Results also showed a strong correlation between the two variable; the coefficient scores were $(0.779,0.928$ and 0.892) on Pearson, Kendall and Spearman coefficients respectively.
\end{abstract}

Keywords: Google Classroom, Communicative Grammar, Attitudes

\section{Introduction}

Technology may not replace teachers but teachers who know technology will replace those who do not know it. In this view, this research highlights the importance of different class language communications with the help of the teacher for an effective foreign language learning virtual environments. For instance, Bryant (2006, p. 1) expresses the view that "You can now master a foreign language or complete a whole degree without leaving the comfort of your sofa. You can decide not only when you want to 
learn but also how you want to learn". With the help of an effective "new" teacher, classes can be run in a virtual learning environment that depends on technology and its widespread applications.

Virtual classrooms are practical implications for the virtual reality, which was first coined in 1988 by Jarod Lanier (Rahimi, et al., 2013). This concept means "a combination of high speed computers, advanced programming techniques and interactive devices designed to make computer users feel they have stopped into another world constructed of computer data" (Grady\& Coiffet, 2003, p.11). Virtual classrooms can lead to distinctive language developments in students' attitude and language performance. Cotton (2001) compared between using both virtual classrooms and conventional or traditional classrooms on language performance and attitudes, results showed that there are significant mean differences between the two research variables' results favoring the use of virtual classrooms.

Google Classroom as a virtual classroom tool is utilized in this research; it is an application that can be downloaded from Google free suit using regular browser or through an Android or Mac enabled devices. Heggart \& Yaoo (2018) identified the benefits and challenges of Google Classroom and the whole Google suit in the following: first, the benefits included active, authentic, deep and frequent student participation. The challenge is mainly in the "accessibility", where students are not willing to participate in a "clunky" or difficult to use applications. Regardless of the challenges, the study highlighted recommending Google Classroom as an effective platform for tertiary education.

\section{Objectives of the research.}

The research aims at the following:

2.1. Designing, a communicative grammar module.

2.2. Instructing the designed module using a virtual classroom tool "Google classroom".

23. Identifying the effect of the module on participants' grammatical use.

2.4. Identifying the effect of the module on participants' attitudes towards grammar use.

\section{Theoretical Framework}

The following review has two-fold aims. The first is to outline and discuss virtual classes emergence in language education. The second is to discuss communicative grammar as a teaching approach. The review includes key studies that dealt with both virtual classes and communicative grammar areas. 


\subsection{Virtual classes}

Virtual classes are conceived as "spaces" where students take a class with the help of certain software. It mainly evolved due to class routine, distance, time, requirements and regular attendance demands. Virtual classrooms have spread worldwide at university level (Arcia \& Castaneda, 2012). Other studies (see Dalgarmo \& Less, 2010, Rahimi, et al., 2013) expressed the view that a well-designed virtual class or "virtual reality classroom" should include three important corners: navigation, realistic manipulation and immersion. Virtual classrooms can be defined (McLellan (2003) to mean a system that can provide the teaching and learning opportunities given by a traditional class and exceed the traditional boundaries of place and acoustic.

History and development of Virtual Classrooms - since its first emergence in 2014- as a technology path in education can be shown in the following figure by (Morquin: 2014); the figure tracks the hardware and the software development as below:

Figure (1) Technology integration timeline from 1981 till 2014

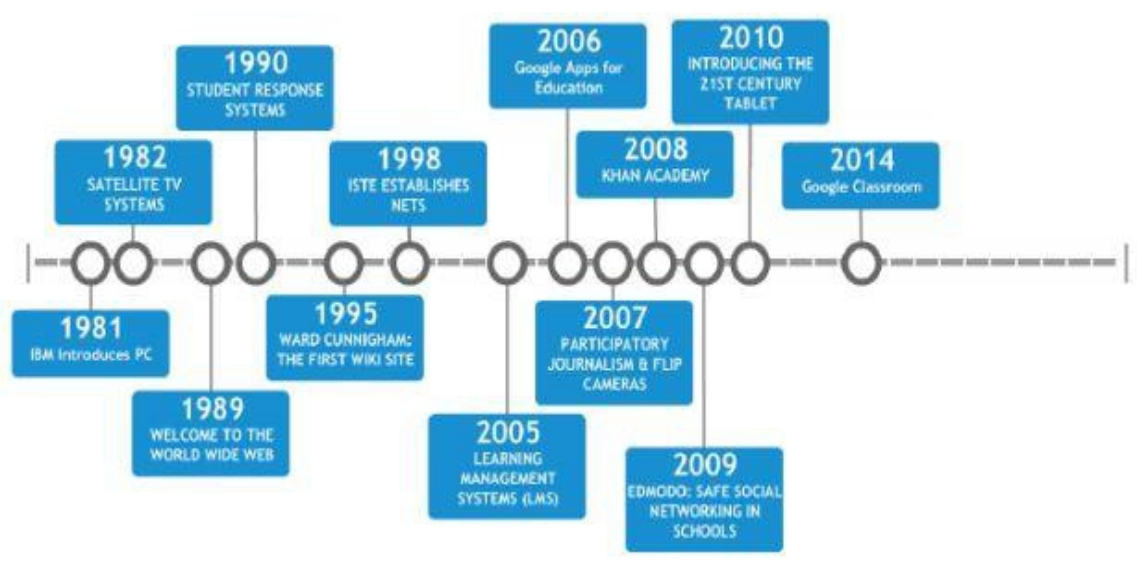

The figure shows the early technology integration in education starting from 1980s which witnessed the use of personal computers followed by the 1990s which witnessed the vast developments in networking and webbing. The 2000s witnessed the first releases of learning systems till the first release of Google Classroom in 2014.

Google Classroom has been used in various educational contexts and activities. For instance, Kultawanich et al. (2015, p.88) pointed out that visual classes "should support four online main stream activities, (a) learning resources section, (b) activity section, (c) evaluation section, and (d) management section ). It was also used in EFL context. In a study about the 
place of EFL in virtual classes, Meziane \& Sari-Mitchel (2014) examined the use of virtual classes in a global language and cultural exchange. Participants were virtually trained from 4 countries, Algeria, India, China and USA. Results showed that virtual classes could develop participants' global communication and cultural awareness. Results of the study confirmed the meaningfulness of learning in virtual classrooms. It also confirmed that virtual classrooms enhance autonomy in a student-based and collaborative learning environment.

Using Google classroom as a virtual classroom also has demerits that are similar to all virtual classes. Disadvantages on virtual classes, according to (Azevedo, 2002, p. 2) stressed "it is a mistake to suppose that very technological innovation has only a unilateral effect. Every technology is as much a burden as it is a blessing". The next section discusses the concepts of communicative grammar and its pedagogical occurrences in virtual classrooms.

\subsection{Communicative Grammar Approach}

Communication as an approach to language teaching emerged since late 1970s and changed the view to class practices and courses. The aim of this relatively new approach is to promote the ability to use language communicatively. Harmer (2001, p. 47) stressed the view that this approach promotes the negotiation of meaning. He further states that "Communication is the feature in teaching and learning languages. Students create opportunities for them to participate in the negotiation of meaning, to perform a range of language functions, and to attend to both language forms and functions". This view of language changed the teaching practices to language skills and language areas including grammar and paved the way to the emergence of Communicative Grammar CG approach.

Defining grammar is controversial due to how scholars viewed it. For instance, El Tanani (2011, p. 42) expresses the view that:

It is obvious from all grammar "definitions" that, it is difficult to give any complete definition of grammar as people have different views of where the parameter lies. Thus, these definitions lead to the fact that grammar consist of certain rules that govern the system of language by which we communicate with each other. For that reason, the study of grammar can help in communication as grammar can be seen as a system consisting of phonology, syntax, semantics and pragmatics".

Grammar definitions has shifted from the mere study of rules that govern language to the rules of how language produces long utterances or sentences using words and their morphology (Millrood, 2001). Based on the various definitions of grammar, nine types of grammar, according to Tanani 
can be identified: prescriptive, descriptive, traditional, theoretical, reference, cognitive, structural, transformational-generative and communicative grammar.

Communicative Grammar CG is deeply rooted and linked to Communicative Language Teaching approach CLT. Both communicative grammar and communicative language teaching emerged as counterparts to mere functional and structural approaches to language teaching and learning in Europe at early 1970s. This shift as Haggag (2013, p. 46) stated that "a paradigm shift from language teaching to language use; this shift is what distinguishes the emergence of communicative language teaching as an approach". CG or functional communicative grammar is an interactive view to language as Zain $(2007$, p.22) argues that "it is concerned with making clear interaction between syntax, semantics, and pragmatics. It focuses on the functional aspects that attempts to count for how language is used".

Communicative grammar teaching is one of two main directions that were dominant in grammar classes. The first is the Grammar-Translation; it focuses on acquiring the student with grammatical structures and the structurebased language even with the direct use of L1. The second is teaching grammar through communication. These two approaches were described by Lindblom \& Dunn (2003, p.46) express the view that "Many teachers feel guilty when they teach grammar directly in the classroom. Grammar has returned as a more balanced viewpoint that is seen as one of the several organizational aspects of communicative competence".

Studies that examined the use of various communicative grammar techniques, programs and frameworks are varied (i.e. Tarigan, 2008, El Tanani, 2011, Richards, 2002, Moumene, 2008, Hamouda, 2011, and Al Karaki, 2016). For instance, Moumene (2008) examined the effect of implementing communicative tasks in foreign language teaching. The study utilized eight different communicative grammar based tasks used in a grammar course books. The packets of instruction are found to promote linguistic competence as well as communicative competence. Similarly, El Tanani (2011) examined the existing grammar teaching techniques for six graders in Gaza strip and suggested framework for teaching grammar communicatively. Results showed that teachers do not use effective grammar teaching techniques; students of the experimental group outfitted the control one due to the communicative grammar approach followed in their instruction.

Following effective communicative grammar teaching techniques may result various advantages. For instance, Wang (2010, p. 131) outlined these advantages in: (a) motivating students' learning with fun, enjoyment and excitement. (b) providing practice on language use and language meaning. (c) creating a supportive learning environment. (d) promoting interpersonal relations. These advantages (ibid) are gained even with use of a traditional 
presentation, practice and produce "3Ps approach". Other gains were introduced in a study by (Rodriguez, 2009), they include learning from the communicative context, grammatical \{accuracy\} and the effective use of targeted structures.

Communicative grammar instruction has moved from the computer Aided Language Learning CALL to the virtual classes. In this review, a light should be shaded over some relevant studies that traditionally examined CALL in developing communicative grammar use, acquisition, and instruction. For instance, (Torlakovic \& Deugo (2004) examined the effect of CALL in grammar instruction. Participants were 21 university students and the software utilized was Adverbial Analyzer, which analyzes the utterances used by the participants. Results showed that computer-based students improved in grammatical performance more than their peers in a traditional teacher-based class. Similarly, Abu Seileek (2007) examined the effect of CALL in grammar instruction. Participants were 128 fresh university students. The study followed the experimental approach with its two-group design. Results showed that CALL program was more effective than the traditional non-communicative course. Based on these results, it can be inferred that CALL is an effective approach in teaching grammar; this paved the way to studies that examined virtual classrooms' effect in developing language areas and performance such as the present study. This study examines the use of a virtual classroom in developing participants' communicative grammar use.

Communicative grammar activities in a virtual classroom share the same objectives effective communication with traditional classrooms. The difference may be in the format, layout or the context that can be added to the communicative activity. Following are two examples for a traditional communicative grammar activity and for a virtual classroom in this module.

Figure (2) Examples of traditional and virtual CG activities

Example (1) (Traditional CG activity)

Example (2): VC example activity

Meyerbeer (2014, p. 123)

\begin{tabular}{l}
$\begin{array}{l}\text { Possive TENSE Activity Intermediate Level } \\
\text { Change the sentences to the passive tense. }\end{array}$ \\
\hline \\
$\begin{array}{l}\text { Ex: [in a restaurant] } \\
\text { A customer eats food. } \\
\text { Food is eaten by a customer }\end{array}$ \\
\hline
\end{tabular}

[in a festaurant]

A waiter serves meals.

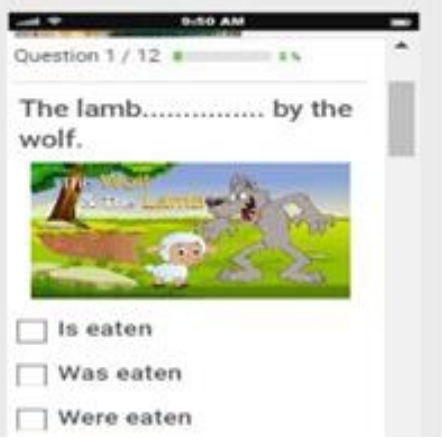


The above examples show that the "communicative" ingredient is almost the same in both the two examples. The differences lie in the abundant features and contextualization to the activity that can be found in the digital pictures, flexible layout and ease of engagement.

\section{Research Hypotheses}

4.1.There are statistically significant mean differences between participants' mean scores on the communicative grammar use favoring the post test.

4.2.There are statistically significant mean differences between participants mean scores in the pre-post tests of attitude towards grammar use favoring the post testing.

4.3.There is a correlation between developing communicative grammar use and attitude towards English grammar use.

\section{Method}

The research followed a quasi-experimental design, where participants were exposed to an independent variable (Communicative Grammar module) and then pre post tests were run. Mean differences were compared using SPSS program for both the communicative grammar skills and attitude towards grammar as well.

\subsection{Participants}

Participants of the research were randomly chosen from the postgraduates General Diploma at Hurghada Faculty of Education, Egypt. An announcement for the course was created on university website that includes the link to the classroom. They were adjusted to department (non-English specialized students), grammar level (Mean score is 15/50), 9 outlier scores were excluded from the course. The final number of the participants were (41) non-English specialized students doing their diploma in education. They were informed to complete their data online using Google document link. All the materials, instruction and even certificates were done virtually. Participants were asked to sign an obligation letter, which explains their roles and duties in completing the free course.

\subsection{Instruments}

The research utilizes the following instruments:

5.2.I. A communicative grammar-based module. The module focuses on the following grammar aspects (Verbs- tenses- sentencesquestions-articles). The module was validated by a jury of EFL experts. They reported it's validly for the objectives of the training. 
5.2.II. An English grammar test. The test aims to assess participants' communicative grammar use. It was validated by a jury of TEFL experts and they reported its content validity. Reliability score of the test was (0.88), which is a high reliability score. The total score of the test is (50). The test covers the areas of (verbsquestions- tenses- sentences- articles). Test accepted score of the participants - in the adjustment phase- was (M. 15) over the total score (50). Below is a figure that shows how obtained results from the test can be grouped.

Figure (3): Example participants' scores from the test

\begin{tabular}{|c|c|c|c|c|c|c|c|}
\hline$A$ & B & C & D & $E$ & $\mathrm{~F}$ & $\mathrm{H}$ & 1 \\
\hline Date & First Name & Last Name & Phone & User IP & Score \% & Time Taken & Result \\
\hline $6 / 10 / 189: 28$ & Ayat & Said & 1003807714 & 196.150 .15 .80 & 53.33 & $24 \mathrm{~min} 15 \mathrm{sec}$ & Pass \\
\hline J6-10-2018 09:04:06 AM & Meret & Sanad & 1287591915 & 197.162 .111 .252 & 63.33 & $16 \mathrm{~min} 41 \mathrm{sec}$ & Pass \\
\hline J6-10-2018 08:48:26 AM & Abeer & Abdo & 1020440880 & 41.238 .163 .185 & 86.67 & $8 \mathrm{~min} 36 \mathrm{sec}$ & Pass \\
\hline J6-10-2018 08:46:11 AM & Samah & Hassan & 1001103609 & 197.43.160.107 & 83.33 & $6 \mathrm{~min} 8 \mathrm{sec}$ & Pass \\
\hline J6-10-2018 08:39:14 AM & Samah & Hassan & 1001103609 & 197.43.160.107 & 80 & $14 \mathrm{~min} 48 \mathrm{sec}$ & Pass \\
\hline J6-10-2018 08:36:21 AM & Aya & Yasser & 1111812591 & 105.89 .83 .89 & 90 & $8 \min 4 \mathrm{sec}$ & Pass \\
\hline J6-10-2018 08:34:10 AM & Randa & Mahmoud & 1091563926 & 196.150 .2 .214 & 70 & $9 \min 14 \mathrm{sec}$ & Pass \\
\hline J6-10-2018 08:28:28 AM & Affaf & Mohamed Sayed & 1113001214 & 156.188 .228 .157 & 36.67 & $19 \mathrm{~min} 14 \mathrm{sec}$ & Pass \\
\hline J6-10-2018 08:23:29 AM & Randa & Mahmoud & 1091563927 & 196.150 .2 .214 & 50 & $16 \min 5 \mathrm{sec}$ & Pass \\
\hline
\end{tabular}

The above table shows how the virtual test spontaneously analyzes the answers and adds details like contacts, pc information, time, score and result. The result can be determined by the teacher through setting a pass score over the test. The obtained score is a sum of the actual score on the test, time taken in the answer and the number of test attempts.

5.2.III. An attitude scale. It aimed at identifying participants" attitudes towards English grammar use. The test was validated by a jury of TEFL experts. The test was piloted for reliability calculation and it was reported to be (0.76), which is a high reliability. The test was utilized for sample adjustment, pre and post testing. The total score of the attitude scale is (100). The scale was used in both the pre and post testing running.

5.2.IV. A web blog. This online instrument aimed to allow students to reflect on their learning process. It allows students to post on assignments, tests and materials of the training. It was also used as a platform for discussion.

\subsection{Delimitations of the research}

The research was delimited to (41) non-English specialized post graduates at Hurghada Faculty of Education. Participants were students 
enrolled at the general diploma, the one-year system. The research was also delimited to five main grammar areas (verbs- tenses- sentences- questionsarticles). As to place delimit, the experiment was conducted at Hurghada Faculty of Education, South Valley University, Egypt.

\section{Design}

The participants (N.41) were randomly selected and adjusted using a communicative grammar test (Mean score 15). The study follows the quasiexperimental design; the one group design. The participants were exposed to the independent variable, which was the grammar module on Google classroom application. The dependent variables are the communicative grammar use and the attitude towards grammar use. The experimented followed the pre and post testing procedure, where the participants were exposed to both the grammar test and the attitude scale before the experiment, then teaching the Grammar module followed by the testing of grammar and the attitude.

\section{Findings and discussion}

The research utilizes three instruments (Grammar test- attitude scale and a Blog) to verify the research hypotheses. Using SPSS statistical program, the following results were obtained and analyzed as follows.

H. 1. There are statistically significant mean differences between participants' mean scores on the communicative grammar skills test favoring the post test.

To answer this hypothesis, a validated grammar test was designed by the researcher. The following table (1) indicates the descriptive statistics of the results. The table shows the differences in means in the two tests for the pre and posttests (14.73 and 18.20) respectively.

Table (1): Descriptive Statistics

Paired Samples Statistics

\begin{tabular}{|ll|c|r|r|c|}
\hline & & & & Std. Error \\
& & Mean & $\mathrm{N}$ & Std. Deviation & Mean \\
\hline Pair 1 & Pretest gram. & 17.73 & 41 & 3.775 & .590 \\
& Posttest gram. & 24.12 & 41 & 4.354 & .680 \\
\hline
\end{tabular}

Table (1) indicates that the scores are greater in the final testing and there is a development in their communicative grammar performance as shown in participants' means. To identify whether this difference in means is significant or not the following treatment was statistically run as table (2) indicates below. 
Table (2) Comparing means

Paired Samples Test

\begin{tabular}{|c|c|c|c|c|c|c|c|c|}
\hline & \multicolumn{5}{|c|}{ Paired Differences } & \multirow[b]{3}{*}{$t$} & \multirow[b]{3}{*}{ df } & \multirow[b]{3}{*}{ Sig. (2-tailed) } \\
\hline & \multirow[b]{2}{*}{ Mean } & \multirow[b]{2}{*}{ Std. Deviation } & \multirow{2}{*}{$\begin{array}{c}\text { Std. Error } \\
\text { Mean }\end{array}$} & \multicolumn{2}{|c|}{$\begin{array}{l}95 \% \text { Confidence } \\
\text { Interval of the } \\
\text { Difference }\end{array}$} & & & \\
\hline & & & & Lower & Upper & & & \\
\hline $\begin{array}{l}\text { Pair } 1 \text { pretestgram - } \\
\text { posttestgram }\end{array}$ & -3.390 & 3.485 & .544 & -4.490 & -2.290 & -6.229 & 40 & .000 \\
\hline
\end{tabular}

Table (2) shows that comparing the two means resulted significant differences at level (0.05). These significant differences in means show that participants' performance in grammar has slightly developed due to the use of the independent variable which is the grammar module on Google Classroom. This result accepts the alternative hypothesis and rejects the null hypothesis. How did this development affect participants' attitudes towards English grammar? The answer to this question is included in the following hypothesis.

H.2. There are statistically significant mean differences between participants' mean scores in the pre-posttests of attitude towards grammar favoring the post testing.

To answer the above hypothesis, an attitude scale was designed by the researcher to assess Participants' satisfaction about using grammar communicatively. Responses of the participants were encoded using a scale from 1-3 with a total of 100 marks for the whole responses. Then, following a pre post analysis using SPSS the following descriptive data were obtained.

Table (3): Descriptive Statistics

Paired Samples Statistics

\begin{tabular}{|ll|r|r|r|c|}
\hline & & & & \multicolumn{1}{c|}{ Std. Error } \\
& Mean & N & Std. Deviation & \multicolumn{1}{c|}{ Mean } \\
\hline Pair 1 & pregrammatti & 51.63 & 41 & 14.834 & 2.317 \\
& postgrammatti & 57.05 & 41 & 16.459 & 2.570 \\
\hline
\end{tabular}

The table shows the difference in means obtained from the pre and post applications of the attitude scales about grammar use. The obtained scores are (57.05) for the post test compared to (51.63) for the pre application. This difference in means was analyzed statistically to verify if it is significant or not. The following table (4) shows the results of this analysis. 
Table (4): Comparing means

\begin{tabular}{|c|c|c|c|c|c|c|c|c|}
\hline & \multicolumn{5}{|c|}{ Paired Differences } & \multirow[b]{3}{*}{$t$} & \multirow[b]{3}{*}{ df } & \multirow{3}{*}{$\begin{array}{l}\text { Sig. (2- } \\
\text { tailed) }\end{array}$} \\
\hline & \multirow[b]{2}{*}{ Mean } & \multirow[t]{2}{*}{$\begin{array}{r}\text { Std. } \\
\text { Deviation }\end{array}$} & \multirow{2}{*}{$\begin{array}{c}\text { Std. Error } \\
\text { Mean }\end{array}$} & \multicolumn{2}{|c|}{$\begin{array}{l}95 \% \text { Confidence } \\
\text { Interval of the } \\
\text { Difference }\end{array}$} & & & \\
\hline & & & & Lower & Upper & & & \\
\hline $\begin{array}{l}\text { Pre-grammar-atti } \\
\text { Pre-grammar-atti }\end{array}$ & -5.415 & 9.265 & 1.447 & -8.339 & -2.490 & -3.742 & 40 & .001 \\
\hline
\end{tabular}

As table (4) shows, there are significant mean differences between the two means at the level (0.05) as the shaded area indicates (.01). This explains the development in participants' attitudes towards English grammar use favoring the post application of the scale. This positive development towards the communicative use of English grammar means that they are satisfies with learning English grammar using this communicative approach to grammar. This result accepts the alternative hypothesis and rejects the null hypothesis. Are there any correlations between using grammar communicatively and the attitude towards English grammar? This is what the following hypothesis is attempting to answer. There is a correlation between developing communicative grammar use and attitude towards English grammar.

To answer the following hypothesis, the following correlation statistics were run. The following statistics identify the means of the two variables, standard deviation and number of the two participants.

Table (5): Descriptive Statistics

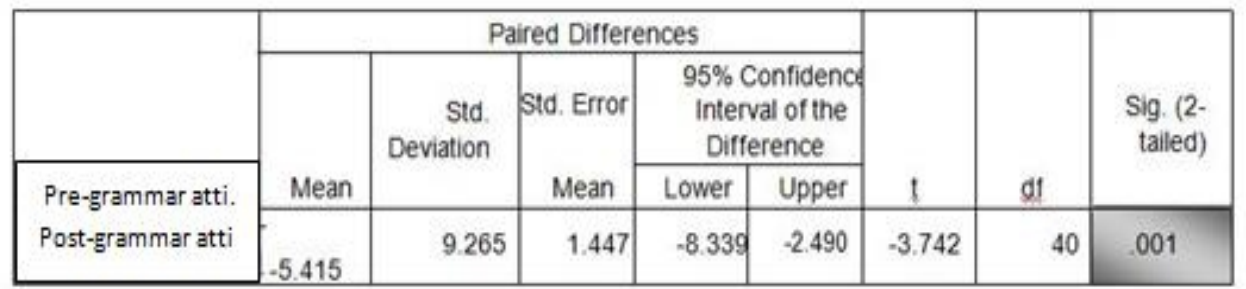

The above table (5) shows that the standard deviation between the participants in the grammar testing was greater than in the attitude scale. This is due to the divert scores of the participants (SD. 16.459) compare to the attitude scores (SD. 4.354). This means that participants' attitudes towards English grammar use are collectively positive and there is almost an agreement to this attitude or satisfaction. The following table indicates the correlation between the two variables. 
Table (6): Pearson correlation

Correlations

\begin{tabular}{|c|c|cc|}
\hline $\begin{array}{c}\text { VAR0000 } \\
2\end{array}$ & VAR00001 & & \\
\hline .045 & 1 & Pearson Correlation & VAR00001 \\
.779 & & Sig. (2-tailed) & \\
41 & 41 & N & \\
1 & .045 & Pearson Correlation & VAR00002 \\
& .779 & Sig. (2-tailed) & \\
41 & 41 & $\mathrm{~N}$ & \\
& & & \\
\hline
\end{tabular}

The above table indicates the correlation value $(0.045)$, which is significant ( 0.779$)$ according to the 2-tailed correlation by Pearson. To verify this correlation in different treatments (Kendall and Spearman), the following treatments were run.

Table (7): Correlation coefficient

Correlations

\begin{tabular}{|c|c|ccc|}
\hline VAR00002 & VAR00001 & & & \\
\hline .010 & 1.000 & Correlation Coefficient & VAR0000 & Kendall's taub \\
.928 & & Sig. (2-tailed) & 1 & \\
41 & 41 & $\mathrm{~N}$ & & \\
1.000 & .010 & Correlation Coefficient & VAR0000 & \\
& .928 & Sig. (2-tailed) & 2 & \\
41 & 41 & $\mathrm{~N}$ & & \\
.022 & 1.000 & Correlation Coefficient & VAR0000 & Spearman's rho \\
.892 & & Sig. (2-tailed) & 1 & \\
41 & 41 & $\mathrm{~N}$ & & \\
1.000 & .022 & Correlation Coefficient & VAR0000 & \\
& .892 & Sig. (2-tailed) & 2 & \\
41 & 41 & $\mathrm{~N}$ & & \\
\hline
\end{tabular}

The above table (7) shows the significance value for both Kendall and Pearson statistics, which were (0.928) and (0.892) respectively. The above score are greater than $(0.5)$ and this means that there is a strong correlation between the two variables. This result establishes a strong correlation between using grammar communicatively and the positive attitudes towards its use. This result accepts the alternative hypothesis and rejects the null one and confirms the positive relationship between the two variables of the study.

\section{Discussion}

The research examined a fairly recent independent variable - Virtual Classrooms- to identify its effect on communicative grammar use as well as 
the attitude towards English grammar. The obtained results from the experiment, which positively developed both CG use as well as the attitudes towards it, agree with many studies that called for CG use instead of rote grammar drilling. For instance, Larsen Freeman (2003)expressed the view that language teachers do not want to focus on grammar structures mastery as it is widely rejected by many practitioners; she further stresses the significance of communicative activities in using the language. She also highlighted the importance of teaching grammar, its functions and use as well.

The results highlight the significance of using Google Classroom in language learning in general and grammar in particular. This result agrees with the studies by (Lank shear \& Knobel, 2014) and (Izenstark \& Leahy, 2015) since it emphasizes the use of learner participation in a technology-aided environment for the purpose of language development collaboratively. The results also agree with the preceding study in stressing the various roles done by the learner in the virtual classroom such as sharing documents, discussion, adding presentations, journaling and reflection.

Motivation and attitude towards Google Classroom use were examined by Fallon (2015) after the release of the classroom by Google in 2014. The obtained result from Fallon's research agrees with the present study ion the scope (developing motivation towards language learning) and agrees in the area (grammar use). This study differs in highlighting the role of virtual classrooms in developing students' motivation towards English grammar use. Attitude towards CLT was measured in a study by (Behrenwald, 2010) that investigated the attitudes of the instructors and professors not the students as in the present study. A significant difference $(\mathrm{p}=0.048)$ was found between the public secondary school group and the college/university group. Instructors at public schools were found to support CLT more than university professors due to grammar instruction issues and designing the environment itself.

The reflection journals by the students emphasized the same results. For instance, Hanan Abdel Gawad added a comment in a reflection journal stating that:

"Today, l got a new experience through Google classroom application in general and Grammar in particular. Really I intend to imitate you with my students next year God Willing and I think it will be fruitful. Today with the pretest I have got some new online expressions in pedagogy".

Similarity, Asmaa Mohamed commented "It's a new way for assessment; I intend to use it with my students soon and also Google Classroom. Amazing application...". These results stress the importance of using virtual classrooms in teaching grammar communicatively. 


\section{Towards a module for virtual communicate grammar classes}

In the light of this research design, procedure and assessment the following module can be suggested for compiling, teaching and assessing mobile learning based communicative grammar modules. The aim behind the model is to set and describe the encompassing of the processes of designing, teaching and assessment in a virtual learning environment.

Figure (4) Model for Communicative Grammar Virtual Modules

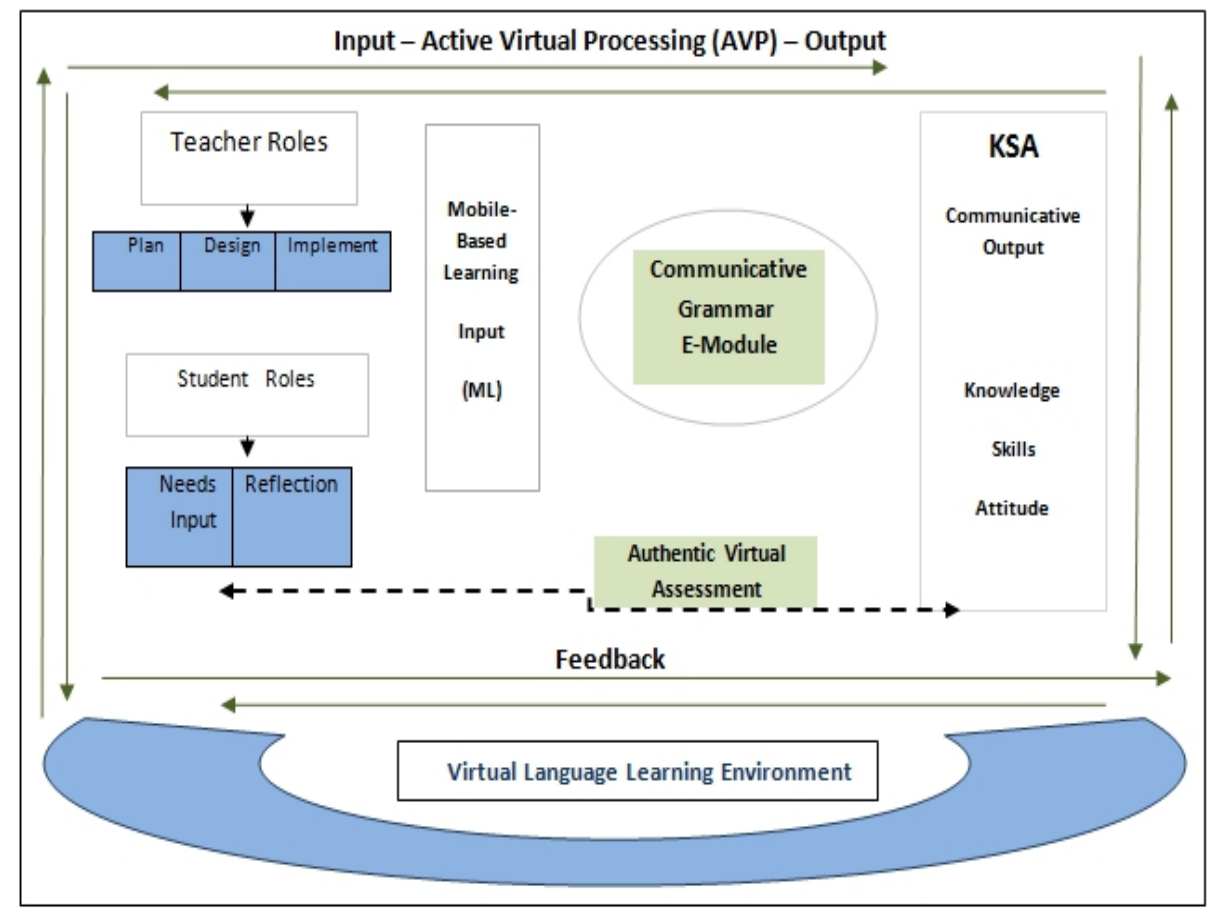

The figure integrated three main layers in the module: the input, active virtual learning processing and then assessment. The first layer (Input) includes the roles of both the teacher and the student in the learning experiment. These roles, though similar to frontal teaching, differ in the virtual confronting and objectives setting from traditional teaching environment. The second layer (AVP) integrates the virtual language module to the Mobile Learning ML setting or carrier (in this research Google Classroom). This layer highlights the interactivity through virtual engagement between the student, the instructor and the content. The third layer "Authentic assessment" integrates both formative and summative assessments in an online assessment process that drives learning. The model highlights the process of feedback and continuous reflection, which also takes the form of virtual learning. This model can guide course designers in the field of EFL virtual classrooms to design, instruct and assess grammar and language classes in general. 


\section{Conclusion, implications \& recommendations}

Implementing a communicative grammar module in a virtual class environment could develop non-English specialized post graduates' grammar use and their attitudes towards English grammar. Following a one-group quasi-experimental design, the obtained results showed a development in participants' grammar use (0.001) and also their positive attitudes (0.001) towards using grammar. Results also indicated a strong correlation between the two variable; the coefficient scores were $(0.779,0.928$ and 0.892$)$ on Pearson, Kendall and Spearman coefficients respectively. Following a communicative approach to course design and instruction methods may result to positive use and attitude towards English Grammar.

Implications of the research can benefit various stakeholders: (a) Course Designers: although following a communicative approach is a current trend in foreign language courses but moving the course to an online interactive module - as in this study- may have further positive impacts on students and learners performance. (b) Language learners: participants in the experiment showed their satisfaction with using the virtual classrooms in learning English grammar, thus, participating in virtual classrooms can develop as language areas or different grammar areas. They may make use of the online activities, practices and tests to develop their grammatical competence and performance. (c) Theory: the suggested model can be added to the literature of EFL course design in the CLT and Virtual Learning VL contexts. Therefore, it can be used as a basis for further studies to identify its effectiveness in other areas of EFL course design.

These results highlight some recommendations suggested by (Uwamahoro, 2014). For instance, (1) providing language teachers with professional development and training in the fields of e-courses and CLT. (2) for an effective classroom, the number of students should be reduced. (3) making available "authentic" CLT based courses and contents. (4) adding CLT as an approach in the national educational strategy for better language outcomes. To establish a successful virtual learning environments, two main types of professional development projects should be pursued; the first is a technical one that aims at developing teachers' technical knowledge with technology. The second is course and content related trainings that enable teachers to supplement, modify and integrate contents to online virtual tools.

\section{References:}

1. Abu Seileek, A., \& Rababah, G. (2007). The Effect of computer based grammar instruction on the acquisition of verb tenses in an EFL context. JALT CALL Journal, 3 (12), 1-17 
2. Al Karaki, G. (2016). The effect of using communicative classroom activities on fourth grader's achievement grammar test at the private schools in Al Karak. MA Thesis, Mutah University, Jordan.

3. Arcia, F. \& Castaneda, J. (2012). Through the teachers' eyes: the use of virtual classrooms in ELT. Colombian Journal for Teachers of English, pp. 76-92

4. Azevedo, W. (2002). Technology: the culture of technology, Retrieved: http:llaquifolium.com/salsa2/2aunidade.html

5. Burdea, G., \& Coiffet, P. (2003). Virtual Reality Technology (2nd ed.). John Wiley \& Sons, New York

6. Bryant, A. (2016). Technology vs. teachers: can technology replace teachers? Retrieved: https://www.kognity.com/can-technologyreplace-teachers/

7. Cotton, K. (2001). Teaching thinking skills.Northwest Regional Educational Laboratory.Retrieved :http://www.nwrel.org/scpd/sirs/6/cu11.htm

8. Dalgarmo, B. \& Lee, M. (2010). What are the learning affordances of 3 -D virtual environments? British Journal of Educational Technology, vol. (41), No. (1), pp. 10-32

9. El Tanani, A. (2011). Teaching Grammar Communicatively for six Graders in Gaza Strip: A suggested framework. MA thesis, Gaza, Palestine

10. Freeman, D. E., \& Freeman, Y. S. (2004). Essential linguistics: What you need to know to teach reading, ESL, spelling, phonics, and grammar. Portsmouth, NH: Heinemann.

11. Haggag, M. (2013). A suggested program based on active learning and its effect on developing TOEFL-iBT-oriented language proficiency of non-English specialized researchers. PhD. Dissertation, KarlFranzens University, Austria

12. Harmer, J. (2001). The practice of English language teaching. Longman,: UK

13. Heggart, K. R., \& Yoo, J. (2018).Getting the Most from Google Classroom: A Pedagogical Framework for Tertiary Educators. Australian Journal of Teacher Education, 43(3). Retrieved from http://ro.ecu.edu.au/ajte/vol43/iss3/9

14. Hamouda, A. (2011). Students' perceptions about communicative and non-communicative activities.

http://serach.mandumah.com/Record/680544

15. Izenstark, A., \& Leahy, K. L. (2015). Google classroom for librarians: Features and opportunitiesnull. Library Hi Tech News, 32(9), 1-3.

16. Kultawanich, K., Koraneekij, P. \& Na-Songkhla, J. (2015). A proposed model of connectivism learning using cloud-based virtual 
classroom to enhance information literacy and information literacy self-efficacy for undergraduate students. Procedia-Social and behavioral sciences, 191, pp. 87-92. Retrieved: www.sciencedirect.com

17. Lankshear, C. \&Knobel, M., \& (2014).Studying new literacy. Journal of Adolescent \& Adult Literacy, 58 (2), 97-101.

18. McLellan, H. (2003). Virtual realities. In D. H. Jonassen \& P. Harris (Eds.), Handbook of research for educational communications and technology (2nd ed.), pp. 461-498. Mahwah, NJ: Lawrence Erlbaum.

19. Meerbeek, M. (2014).Teaching grammar communicatively to beginning and intermediate Arabic speaking ELLS.Master Thesis, Saint Mari's College of California

20. Meziane, M., Sarti-Mitchel, S.(2015). Teaching with technology: The place of EFL in virtual classrooms. International Journal of Linguistics and communication. Vol. 2, No. 1, pp.67-79, Doi: 10.1111/j.14678535.2009.01038.x

21. Millrood, R. (2001). Modular Course in ELT Methodology. London: Macmillan press .

22. Behrenwald, S. ( 2010). Teacher perspectives on communicative language teaching in Ukraine. MA thesis, ProQuestLLC

23. Rahimi, A., Golshan, N. \& Mohebi, H. (2013). Virtual reality as a learning environment in Iranian EFL context: personal, technical, and pedagogical. Procedia-Social and Behavioral Sciences, Vol. 136, pp. 234-239, Doi: 10.1016/j.sbspro.2014.05.320

24. Richards, J. (2002). Addressing the Grammar Gap in Task Work. In I.C. Richards and W.A. Renandya (eds.). Mythology in language teaching: An Anthology of Current Practice. Cambridge: Cambridge University Press

25. Rodriguez, A. (2009). Teaching Grammar to Adult English Language Learners: Focus on Form. CAELA network Brief. Retrieved: www.cal.org/ caelanetwork/pdfs/teachingGrammar finalWeb.pdf

26. Tarigan, B. (2008).Teaching English Grammar Communicatively in an Indonesia University. Unpublished MA Thesis. University of Sumatera Utara.

27. Tarlakovic, E, \& Deugo, D. (2004). Application of a CALL A system in The Acquisition of Adverbs in English. Computer-Assisted Language Learning, 17 (2), 203-235.

28. Uwamahoro, G. ( 2014). Rwandan University EFL Teachers' Awareness and Attitudes Toward CLT and their Classroom Practices. MA Thesis, Minnesota State University, Mankato 
29. Wang, F. (2010).The Necessity of Grammar Teaching. English LanguageTeaching3/2:78-81.Retrieved: http://www.ccsenet.org/ journal/index.php/ elt/article/view/6241

30. Zain, S. (2007).Teaching of Grammar: teachers' Beliefs, Instructional Contexts and Practices. MA Thesis, University of Sains Malaysia

Appendices

Appendix (1): Tables\& figures

\begin{tabular}{|c|c|}
\hline Tables & Description \\
\hline 1 & H1: Comparing means \\
\hline 2 & $H 1:$ Descriptive Statistics \\
\hline 3 & $H 2:$ Comparing means \\
\hline 4 & Hescriptive Statistics \\
\hline 5 & H3: Pearson correlation \\
\hline 6 & Correlation coefficient \\
\hline 7 & Description \\
\hline Figures & Examples of traditional and virtual CG activities \\
\hline 1 & Example participants' scores from the test \\
\hline 2 & Model for Communicative Grammar Virtual Modules \\
\hline 3 &
\end{tabular}

Appendix (2)

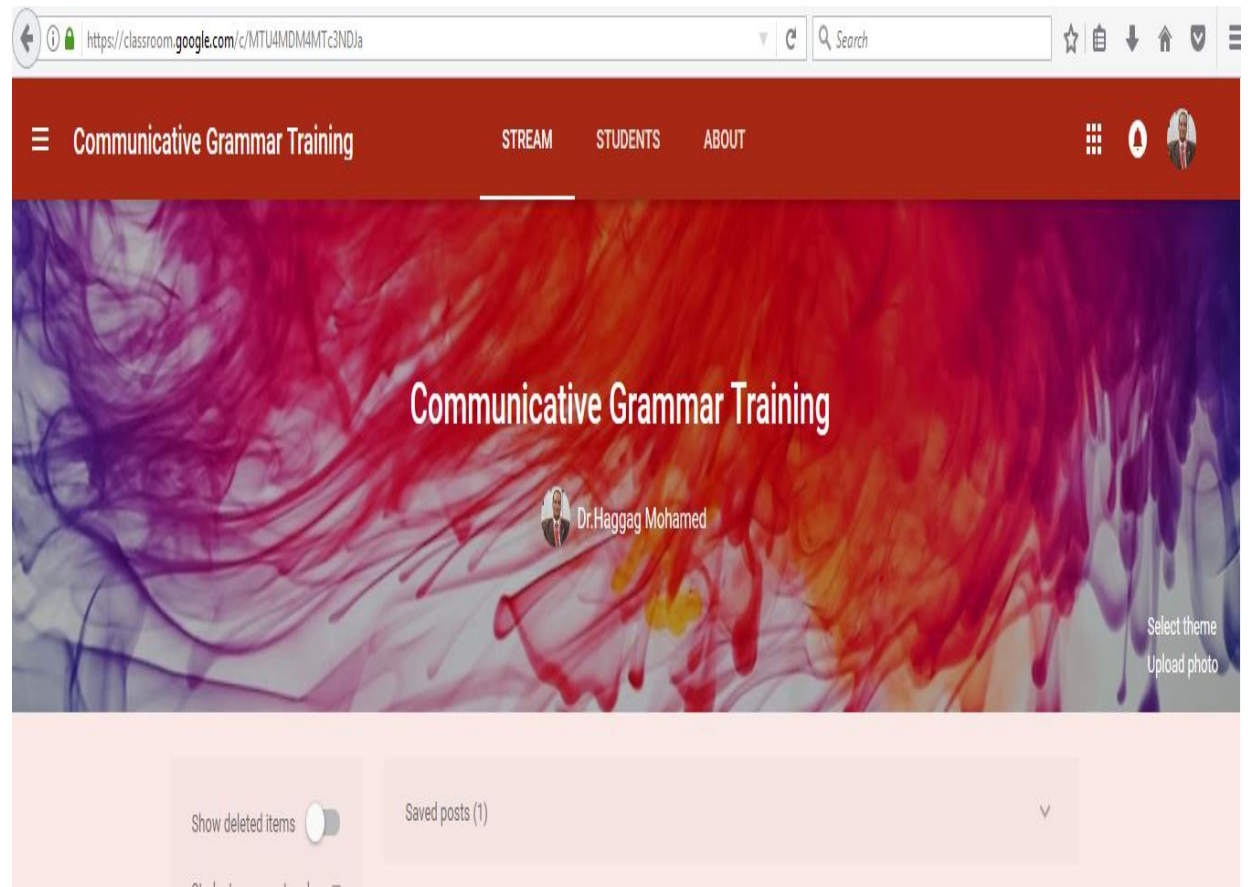


Appendix (4)

\section{Attitude towards English Grammar Use Scale}

\section{Directions:}

These items state your feeling and attitude about English Grammar use.

Kindly use the scale below to circle the response that most closely resembles your opinion.

\begin{tabular}{|c|c|c|}
\hline 1 & 2 & 3 \\
\hline Disagree & Neutral & Agree \\
\hline
\end{tabular}

\begin{tabular}{|c|c|c|c|c|}
\hline No & Items & $\begin{array}{c}1 \\
\text { Disagree }\end{array}$ & $\begin{array}{c}2 \\
\text { Neutral }\end{array}$ & $\begin{array}{c}3 \\
\text { Agree }\end{array}$ \\
\hline 1 & Grammar is easy to learn and master. & & & \\
\hline 2 & $\begin{array}{l}\text { Language can be learned without } \\
\text { grammar rules. }\end{array}$ & & & \\
\hline 3 & $\begin{array}{l}\text { Learning grammar needs a lot of effort } \\
\text { and time. }\end{array}$ & & & \\
\hline 4 & I feel unsafe during grammar tests. & & & \\
\hline 5 & $\begin{array}{l}\text { Fluent speakers are not accurate in } \\
\text { grammar. }\end{array}$ & & & \\
\hline 6 & $\begin{array}{c}\text { Grammar is not important for work or } \\
\text { business communication. }\end{array}$ & & & \\
\hline 7 & $\begin{array}{l}\text { Grammar is not important for } \\
\text { communication. }\end{array}$ & & & \\
\hline 8 & $\begin{array}{l}\text { Studying English grammar is time and } \\
\text { effort consuming. }\end{array}$ & & & \\
\hline 9 & $\begin{array}{c}\text { If you know all grammar rules, you } \\
\text { master the language. }\end{array}$ & & & \\
\hline 10 & $\begin{array}{c}\text { Learning grammar online is easier and } \\
\text { more interesting. }\end{array}$ & & & \\
\hline 11 & I do not trust my results in grammar. & & & \\
\hline 12 & $\begin{array}{l}\text { I do not like grammar exercises, tests } \\
\text { or quizzes. }\end{array}$ & & & \\
\hline
\end{tabular}




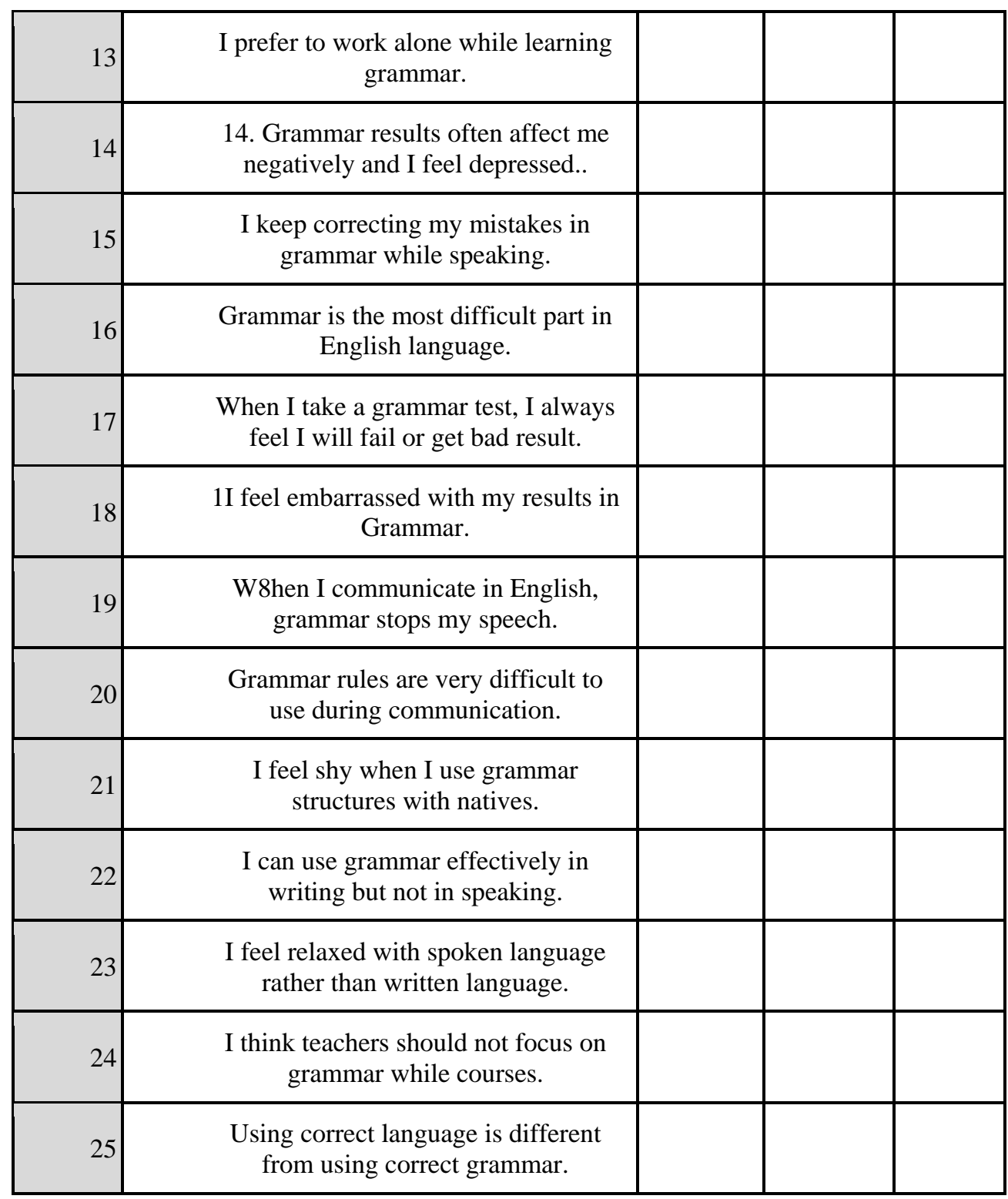

Thank you

Dr. Haggag Mohamed Haggag 


\section{Appendix (4)}

\section{Grammar Test}

Link to test: https://www.proprofs.com/quiz-school/story.php?title=copy-ofhow-good-are-you-at-grammarp3

$\Rightarrow$ (i) (1) A https://www.proprofs.com/quiz-school/story.php?title=copy-of-how-good-are-you-at-grammarp3

\section{Proprofis \\ Quiz Maker}

Copy Of How Good Are You At Grammar?

\section{Copy Of How Good Are You At Grammar?}

30 Questions | By Doctorhaggag | Last updated: Jun 10, 2018 $\star \star \star \star \star \star$

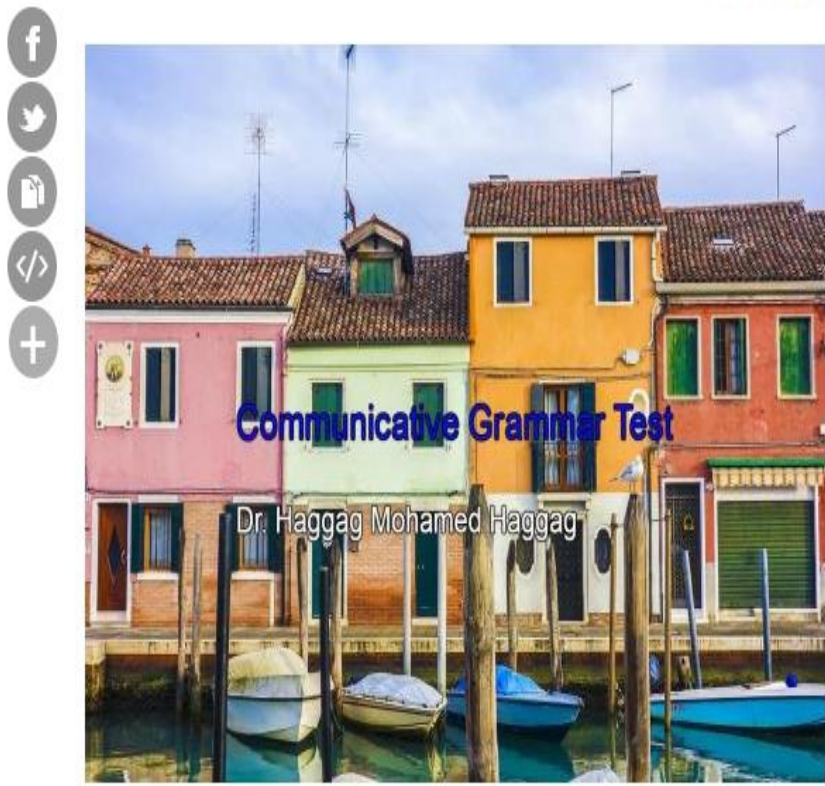

Please answer these grammar questions. Find out your score at the end. 